\title{
Youth Development and Conflict Resolution in Nigeria: Assessment and Intervention Strategies
}

Victor E. Dike ${ }^{1}$ (iD)
Ngozi I. Dike ${ }^{2}$ (ID
${ }^{1}$ Founder/CEO Center for Social Justice \& Human Development (csjhdev), Sacramento, California,
USA
2Lecturer in the Department of Biology, Federal College of Education, Zaria, Nigeria

\begin{abstract}
This article explores youth development, social conflicts and unrest that often degenerates into violence and threaten Nigeria's sociopolitical stability, economic growth and development. In spite of the promises by the successive political leaders and policymakers that youth development will be given priority attention Nigeria has an army of unskilled, jobless and poverty-stricken youth who are prone to anti-social behavior and violence because many of them appear to lack home and community supports as well as economic opportunities. This article argues that investment in positive youth development programs is the key to empowering them with the skills and knowledge to grow into productive and responsible adults; it also helps to improve their living conditions, take care of others as well as to resolve social conflicts effectively. Drawing from available pertinent literature this article will, through descriptive design and in-depth analysis, recommend strategies to assess the efficacy of youth development programs and manage, control or resolve conflicts in Nigeria.
\end{abstract}

Keywords: Youth development, Skills acquisition, Conflict resolution, Intervention, Assessment, Strategies, Adult role model, Community development, Nigeria.

\section{Contents}

1. Introduction...

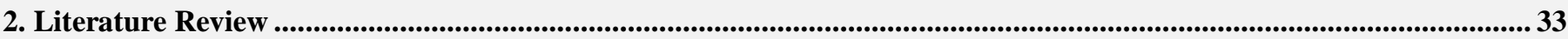

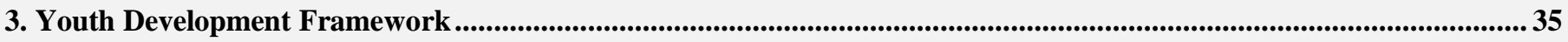

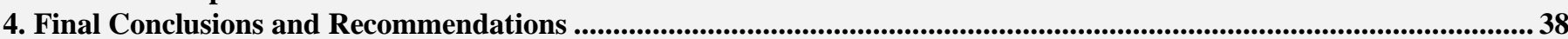

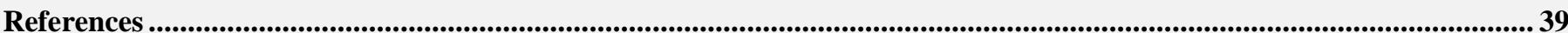

Citation | Victor E. Dike; Ngozi I. Dike (2017). Youth Development and Conflict Resolution in Nigeria: Assessment and Intervention Strategies. Asian Journal of Education and Training, 3(1): 30-42.

DOI:

$\operatorname{ISSN}(\mathbf{E})$ :

Licensed:

Contribution/ Acknowledgment:

Funding:

Competing Interests

Transparency:

Ethical:

History:

Publisher:

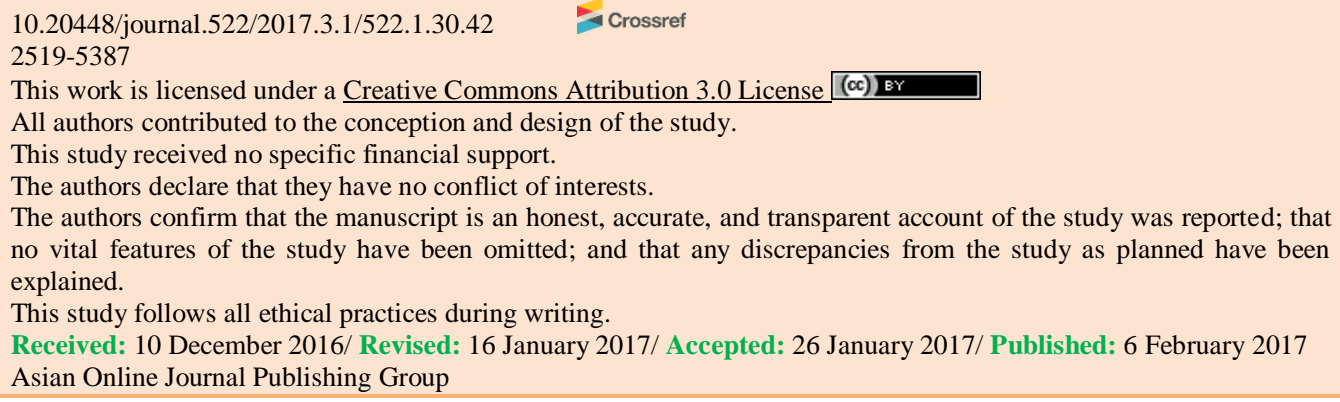

The authors confirm that the manuscript is an honest, accurate, and transparent account of the study was reported; that no vital features of the study have been omitted; and that any discrepancies from the study as planned have been explained.

This study follows all ethical practices during writing.

Received: 10 December 2016/ Revised: 16 January 2017/ Accepted: 26 January 2017/ Published: 6 February 2017 Asian Online Journal Publishing Group 


\section{Introduction}

This article focuses on having a better understanding of the processes, approaches, principles and practices of youth development and conflict resolution in Nigeria as well as the assessment and intervention strategies to empower the youth with the skills and knowledge to participate in peacebuilding and conflict resolution. The problem facing youth development and conflict resolution strategies have been noted (Sacramento, 2013; Youth Development Network, 2014). The youth need programs that will provide them "life-changing experiences" to enable them "thrive and succeed" as adults (YDN, 2014). Conflicts permeate all areas of human existence as they are common in families and organizations; they range from inter-tribal conflicts, religious conflicts and social conflicts, political conflicts and economic conflicts (Sacramento, 2013).

Conflicts also exist at institutional levels (educational conflicts), regional (or community) levels and international levels (Okoh, 2005). Individuals are subjected to internal (intra-personal) conflicts, group conflicts and external conflicts. Each conflict category is said to require a different attention (Sacramento, 2013). Unresolved conflicts could result in violence, which would lead to loss of life and destruction of property. In Nigeria, as in other countries around the globe, conflicts are caused by varied forces with diverse implications (Francis, 2012a; Igbinijesu, 2013). For instance, Nigeria is currently dealing with the Niger Delta conflict caused by environmental damages from oil spillage as a result of operations by oil corporations. Conflict between the communities and oil companies is, thus, prevalent (Okoh, 2005).

The long-running misunderstanding between the Federal Government and the Academic Staff Union of Universities (ASUU)-a union of university academic professors founded in 1978-has disrupted the academic calendar of higher institutions for months (Akinnaso, 2013). The universities in the country have also been battling cultism that has destroyed some lives and property (Aina, 2003). Conflicts over the sharing of resources have also been prevalent in the society. The relentless drop in global oil prices is also putting enormous pressures on the government that lacks any lasting solution to the problem, leading to socioeconomic crisis. Thus, Nigeria, as the nation, is facing severe economic crisis with the naira depreciating in the black market, as demand for the US dollar continues to rise. The poor monetary policy of the Central Bank of Nigeria (CBN), including restriction on foreign exchange, has worsened the situation. Additionally, the severe fuel scarcity has resulted in hours of queues at fuel stations while other stations are closed because of lack of fuel supply. This has created an economic hardship that could lead to social violence! Worse still, the Boko Haram (a militant Islamic group) onslaught (Aina, 2003; Carson, 2015) in the northeast is threatening to destabilize Nigeria. According to report by Kieran Guilbert of Thomson Reuters Foundation, on December 22, 2015, the United Nations have noted that the Boko Haram violence has forced 'one million children out of school in northeast Nigeria and neighboring countries (Cameroon, Chad and Niger) exposing them to "abuse, abduction and recruitment by armed groups".

For some time now communities of Aguleri and Umuleri in Anambra State, the Brass and Nembe communities of Bayelsa and Rivers State, among other communities, have witnessed civil unrests and conflicts stemming from boundary disputes. The Bakassi Peninsula, which is the international boundary between Nigeria and Cameroon, is also in dispute (Igbinijesu, 2013). This is not to mention the Nigeria/Biafra conflict (July 6, 1967 through January 15, 1970) caused by a combination of factors, including political, economic, ethnic, cultural and religious forces among people from different regions. The youth can help to resolve a conflict only when they have in-depth knowledge of the conflict and the skill. Conflict is costly and inherently adds to business risk (Ross, 2006; Kaplan and Mikes, 2010; Davis and Franks, 2014). Before we continue, it is imperative to have a conceptual clarification of the terms in discourse.

\subsection{Conceptual Clarification}

These areas noted above serve as laboratory for conflicts and their implications on national and community development (Banfield et al., 2005). While crisis continues to propel skyward at a disturbing rate in the society the leaders continue to give promises they cannot fulfil. Some scholars, educators and stakeholders perceive conflict as the "basic unit for understanding social existence" (Nnoli, 1998).

For others, conflict is the pursuit of incompatible interests and goals by different groups (Best, 2006a). Conflict, among other things, is a struggle over values or claims to status, power, and scarce resources in which the aims of the parties are not only to gain the desired values, but to neutralize, injure, or eliminate the rivals. Conflict will escalate if not resolved on time and amicably (Best, 2006b). The causes of conflict are many, including social, religious, political and economic factors. Conflict can also arise because of miscommunication between people with regard to their unmet needs, ideas, beliefs, goals, or values.

As if the crowded definition is not enough, other scholars have added that "conflict is perceived as a sense or perception, whether real or imagined, by one entity/person that his/her primary self-interests are being threatened by another entity" (Uwazie et al., 2008). Since "conflict is inevitable in any social interactions or human relations" (Uwazie et al., 2008; Sacramento, 2013) the challenge hinges on its management, control, or resolution.' However, prevention of conflicts, "although often desirable, may not be possible at all times" (Uwazie et al., 2008; Sacramento, 2013).

Some conflicts/disputes produce good results (some provide useful life experiences and lessons (growth and happiness), while others yield negative results. Irrespective of its occasional positive results, 'conflict could be damaging, painful and costly, when and if, ignored or repressed, or when the only responses to conflicts are selfhelp, violent/forceful behaviors of parties or total avoidance' (Uwazie et al., 2008; Sacramento, 2013).

Adopting an effective conflict resolution strategy is, therefore, desirable in every crisis situation. Conflict resolution is a form of 'crucial conversation' as it involves tough issues. It 'is the types of discussion between two or more people where stakes are high, opinions vary and emotions run strong' (Patterson et al., 2002). Resolution is, therefore, an act of finding a lasting solution to problems or a conflict (Burton, 1990). This can be achieved through well-planned and executed conflict resolution strategies. 
When a society, a person or an organization has a problem, the first instinct will be to find a solution(s) to the problem (Kahane, 2005). A well-designed strategy is a symbol of action that will enable the authorities to achieve the desired goal-whether it is changing the behavior of a people or engineering a social change. A strategy is a "game plan" to achieve one or more goals; it is a plan, a "how" and "a means of getting from here to there" (Mintzberg, 1994). Conflict resolution strategy is, thus, a method developed for peaceful and amicable means of ending a state of conflict/dispute. It is also a variety of approaches adopted for settling conflicts through the utilization of amicable and constructive ideas (Miller, 2003).

It is imperative to learn how to manage conflict in all human endeavors. Thus, any person who wants to get involved in conflict management must first acquire the knowledge and skills related to conflict resolution, conflict modes, conflict resolution communication skills and establish a structure for managing conflict (Uwazie et al., 2008; Sacramento, 2013). When selecting a conflict resolution strategy the first decision to deal with is whether or not to confront or avoid the conflict (Umstot, 1987). But "violence is often preceded by prolonged period of silence; [or] after allowing unresolved problems to build up and then boils over,...(Umstot, 1987). Thus, "inability to work through tough issues devastates individual, ruins families, and poison communities" (Patterson et al., 2002).

However, when confronted with conflict, human beings may respond to the situation in different ways, including avoidance (moving away from the source of the conflict, or psychologically tuning off), accommodation (giving the other party whatever they want and expecting little or nothing in return), and competition ("My way" or nothing; "I win, you lose"). Others include, compromise ("I will meet you in the middle" or half way); and collaboration ("our way"; "win/win") (Uwazie, 2008; Uwazie et al., 2008; Thomas and Kilmann, 2010; Uwazie and Yamshon, 2013).

The recurring crises in Nigeria (or in any other society) have tremendous effects, not only on the nation's political stability, but on national development. The youth in Nigeria who appear to be lacking the social support and economic opportunities, and who often think that they are invincible, seize every opportunity to get into violent activities. Some of them in higher educational institutions get involved in cultism, among other violent and unlawful activities (Aina, 2003).

There is no single definition of what constitute the 'youth' as definitions vary from countries and organizations. For instance, the United Nations General Assembly has defined the youth as young people (boys and girls) between the ages of 15 and 24 (International Labour Organization (ILO), 2010) In Nigeria, the youth comprises those in the age group of 18-35 (Federal Republic of Nigeria, 2001; Onyeizugbo, 2007) in Britain, it is those in the age group of 16-18 (Cuddy and Leney, 2005) in Northern Italy, it is those in the age group of 14-29; and in Southern Italy, it is those in the age group of 14-32 (O'Higgins, 1997). But in Jordan, the lowest age range for youth is 12; and it is 35 in a number of African countries, including Sierra Leon and Rwanda.

In practice, however, what constitute youth is said to be better understood as a transitional stage in life between childhood and adulthood, rather than on age (TWB, 2005; The World Bank, 2007). Therefore, 'youth is a period of life coming between childhood and maturity or adolescence; it is an early stage of growth or existence' (Webster's New World College Dictionary, 2001). Like in every living thing, human beings go through stages or steps in growth or development. The youth are affected by an array of social and economic problems that require serious attention, including poor education, high unemployment/underemployment, poverty, HIV/AID and other sexual transmitted diseases (United Nations Population Fund (UNFPA), 2012).

In Nigeria, which is the main focus of the discourse, the youth constitute over 47 per cent of the estimated 170 million people in the country. It is projected that the population of the youth (10-24) of age will be hovering around 73 million by 2025 and 116 million by 2050 (National Population Commission (NPC), 2013). The growing number of the youth makes it imperative for the political leaders and policymakers to give priority attention to issues that affect them in policy decision and implementations. Like in social development, youth development is a process of human growth through which young people are nurtured to move from being taken care of by adults to taking care of themselves and others in the community in which they live (Leftkovitz et al., 2014).

As in most African countries (or Sub-Saharan African countries), the youth in Nigeria appear to be lacking the knowledge and skills to handle their own internal crisis and to participate effectively in conflict resolution. The government should, therefore, invest copiously in youth development programs backed by effective principles and best practices to meet their myriad needs for political stability, economic growth and development of Nigeria.

Achieving this objective is not an easy feat in Nigeria given the country's inept leadership and governance and corruption that is littering the political landscape (Dike et al., 2014). For Nigeria to become an economically prosperous and politically stable society, the policymakers should, therefore, change their "mindset" (Dweck, 2007) and begin now to restructure the economy, plan, and design and implement effective youth development programs to empower them with the skills and knowledge to succeed in life, including training them in conflict resolution strategies.

\subsection{Purpose}

The purpose of this article is to explore the processes, approaches and principles of youth development and conflict resolution strategies as they relate to Nigeria. It will also assess the intervention strategies to the constructs and offer some approaches to plan, design and implement youth development programs that will empower them with the skills and knowledge to reach their full potential as adults and contribute to the well-being of the society.

\subsection{Research Methods}

Information for this descriptive article was derived from extensive review of pertinent literature for an in-depth analysis of the issues surrounding youth development, conflict resolution and the intervention strategies in Nigeria. The sources of the information were thoroughly evaluated and analyzed to determine their authenticity. 


\subsection{Research Questions}

This article focuses on the following questions. 1) What youth development initiatives can enhance the knowledge and skills of the youth in Nigeria? 2) How will youth program directors know if the youth have acquired the intended knowledge, skills and dispositions to grow into productive adults? 3) What are the major sources of youth related conflicts in Nigeria? 4) What conflict resolution strategies (CRSs) will resolve the recurring conflicts in the society?

\section{Literature Review}

Discussions on youth development programs and conflict resolution strategies are not new because there have been a growing number of scholarly work on the approaches, processes and principles on the constructs. In particular, the problems facing youth development initiatives that empower youth with the knowledge and skills to become successful and productive adults (U.S. Department of Health and Human Services, 1996; Community, 2002; Pittman et al., 2002; Teipel, 2002) have made this study much more compelling.

However, "positive youth development," which is the focus of this article, is a policy viewpoint that emphasizes providing social support and economic opportunities to the youth to enable them develop "a sense of competence, usefulness and belonging and empowerment" has equally attracted the attention of scholars and analysts (Positive Youth Development and Policy: "What is Youth Development; see htt://cyd.aed.org/whatishtml). Although individual programs can provide youth development activities, 'the youth development approach' works better when an entire community, including the youth, is involved in developing the programs (Community, 2002). This approach helps to create a range of services and opportunities that the youth need to become happy and "healthy adults" (Positive Youth Development, 2001).

Youth development is thus, about people, programs, institutions and systems that provide the youth, both 'troubled' or not, 'with the supports and opportunities they need to empower themselves' (PYD, 2001). Youth development focuses on the issues that are crucial to the 'youth development approach' (Teipel, 2002). However, 'youth development strategies' focus on giving the youth 'the chance to form relationships with caring adults, build skills, exercise leadership roles, and help their communities'(Center for youth development and policy: What is youth development? See online- http://cyd.aed.org/whatis.html). The underlying philosophy here is all-inclusive, focusing on the development of assets and competencies in the youth. For the writers of this paper, youth development is about adults building healthy relationship with the youth and teaching them social and academic skills that will enable them growth into productive and successful adults. The youth will certainly misbehave as they grow up, but how we response to their misbehavior is what matters.

The youth are viewed as valued and respected asset in every society; and social policies and programs should focus on their evolving developmental needs and tasks as adolescents. The future of every society depends on the welfare of the youth. They perceive the youth as partners rather than clients; and families, schools and communities are engaged in creating environments that support the youth (Teipel, 2002). Caring adults are involved in activities that enhance their 'competence, connections, character, confidence and contribution to society. They are also being provided an opportunity to experiment in a safe environment to develop positive social values and norms and "engage in activities that promote self-understanding, self-worth, and a sense of belonging and resilience" (Teipel, 2002).

Research by scholars, organizations and institutions on youth development programs has acknowledged the 'essential component' that the youth need. Prominent among them are safety, structured places to learn, and links to basic services that will enable them to function effectively within the society (PYD, 2001; Center for Youth Development and Policy, n.d). Other researchers and analysts have also emphasized "personal and social assets" that support the youth's "well-being and outcomes of community program participation" (Leffert et al., 1996; National Research Council on Community Programs to Promote Youth Development, 2002). But for 'positive youth development program' to be successful the designers should 'develop standards and assessment tools' for ensuring physical and psychological safety and provide appropriate structure and supportive relationships. Other features include giving the youth opportunities to belong regardless of one's gender and ethnicity and provide them positive social norms. They include rules of behavior and expectations, values and morals. Others are obligations for service and support for efficacy and integration of family, school, and community efforts into the programs (Leffert et al., 1996; NRCCPPYD, 2002).

Research by the writers of this paper concur with scholars that have argued that for these components to be effective, youth development programs must include practices that embrace supportive environment and responsive and meaningful challenge and practices, which focus on improving their conditions. That means that the programs must have 'built-in opportunities for skill-building, including opportunities to learn physical, intellectual and psychological skills, emotional, social and communication skills, good habits of the mind as well as preparation for adult employment and opportunities to develop social and cultural capital' (Leffert et al., 1996; NRCCPPYD, 2002).

Successful and 'positive youth development' will depend, among other things, upon the quality and competencies of the staff implementing and directing the programs. In other words, the individuals and organizations/institutions that work with the youth should seriously be engaged in youth development with evidence that they are providing genuine strategic social supports and economic opportunities to enable them become successful in life. The 'supports' and 'opportunities' provided should give the youth the chance to experiment with ideas, behaviors and different roles. Above all, "the services must be of good quality in the areas of education, health, employment, and juvenile justice" (Center for Youth Development and Policy, n.d).

The term, youth development, is applied in at least three different ways. It is used as a natural process of development, principles and practices, all of which are important, and logically related (Hamilton et al., 2004). As a natural process, youth development leads to the growing capacity of the youth to understand and act on the environment in which they live. This term and its usage are identical to child or adolescent development. Human development is, therefore, a natural growth inherent in human beings in relation "to the challenges and supports of 
the physical and social environment" (Hamilton et al., 2004). Development in the youth, therefore, enables them to lead a healthy, satisfying, and productive life after which they transit into adulthood where they develop the competence to earn a living as they engage in public or private activities. But one must understand that human beings have different levels of aspirations and interests that can shape their pace of development through the choices they make in live (Hamilton et al., 2004).

Youth development is also a set of principles or philosophy and approach that emphasizes 'active support for the growing capacity of young people by individuals, organizations, and institutions, especially at the community level' (Hamilton et al., 2004). However, youth development approach appears to be ingrained in a society's commitment to help the youth to thrive. Literature shows that initially, youth development emphasized 'problem prevention and treatment programs' as youth practitioners would classify individuals according to their shortfalls and try to cure their deficits' (Hamilton et al., 2004). Certainly, if all the youth are to thrive, some of them would need 'preventive measures' while others would require some 'treatment' (Hamilton et al., 2004). In youth development, practices are utilized "to describe a range of practices in programs, organizations and initiatives" (Hamilton et al., 2004). In this sense, 'youth development' refers to the application of the principles to a planned set of activities that foster the developmental process in the youth. According to research, the distinction between principles and practices is 'especially useful when considering the contexts in which the youth spend their time. Thus, youth 'development takes place in families, neighborhoods, youth organizations, faith-based organizations, schools, and a multitude of other places, including cyberspace'. Although "the specific practices that adults use to create and sustain such opportunities differ across settings, the principles are consistent" (Hamilton et al., 2004).

Literature shows that youth development and conflict resolution can be defined in varied ways given the lens through which the writers view the constructs. "Youth development" is also perceived by some writers as a policy and "community approach" focusing on empowering the youth to achieve healthy results and transition into thriving young adults (Gambone and Connell, 2004). Others have observed that proper youth education and youth programs will lead to "youth development" as they have the potential to equip them with the knowledge and skills to resolve conflicts, when and if, they arise (Youth Development Guide: Engaging Young People in After-School Programming, 2001; YDN, 2014).

As mentioned earlier, human beings are prone to conflicts because it is a product of co-existence of individuals of different personalities. As a result, conflict has been defined as the pursuit of discordant interests and goals by different groups (Best, 2006a). Conflict also indicates differences of opinion, misrepresentations, discrepancies, and bitterness prevailing in a particular organization/society or between individuals. But this is different from "armed conflict," which "is the resort to use of force and armed violence in pursuit of incompatible and particular interest and goals" (Francis, 2012b).

When analyzing dispute/conflict one should approach it through the "categories of conflicts", because no single solution would fix all disagreements. Social scientists, practitioners and analysts have espoused myriad theories as the root causes of conflicts/disputes. That means that there is no single, unified and complete explanation to the causes of conflicts. Theories on the causes of conflicts/disputes are said to fall into five categories (Sacramento, 2013) Data disputes: it perceives conflict as revolving around or being created by information (or misinformation, lack of information or unfamiliar information); 2) Structural disputes: they are said to occur within or between institutions and or bureaucracies (the struggle of social factions hostile to each other); 3) Value disputes: they are caused by a clash of ideas or belief systems (example are issues arising from values tied to communism and capitalism or entrenched moral belief); 4) Relationship disputes: they are very common among human beings or organizations where there are clashes in behavior or commercial relationships; and 5) Behavioral disputes: they can be caused by clashes in habits, behavior, custom and or culture (Sacramento, 2013).

Other theories about the causes of conflicts include unbearable long-lasting moral difference, such as fundamental moral, religious and personal values that cannot be changed easily (Barnett and Littlejohn, 2002) and issues of justice such as when people believe that they are being treated unjustly or unfairly (Deutsch, 2000). Yet, others include right-based grievance such as when one person or group of people makes a demand on another group and it is rejected particularly when they advance their claim as 'rights' (Cassese, 1990; Glendon, 1993) For others, the causes of conflict are unmet or unfulfilled human needs such as basic needs for food, water, and shelter as well as complex needs such as safety, security, self-esteem, and personal fulfillment (Burton, 1990) as well as identity issues such as when a group feels that their sense of self is under threat (Coleman, 2003). However, 'There is nothing as practical as a good theory' (Lewin, 1952). Another good theory that explains the cause of conflict is grievance theory (Collier and Hoeffler, 2000) as noted earlier. Three types have been identified: i) hatreds between groups; ii) political exclusion; and iii) vengeance (Collier and Hoeffler, 2000). Also, indoctrination of a group against others can lead to conflict or crisis.

Yet, another theory on conflict is economic theory, which states that poverty and unemployment could lead to political protest, civil unrest or rebellion (Collier, 2006). However, rebellion, like "armed conflict", is a different matter as it requires financial backing, and thus, a more serious conflict (Collier, 2007). But others seem to believe that rebellion will occur when it is possible no matter the condition (Ali, 2009). Another theory is branded relative deprivation theory, which hinges on economic inequality (Box-Steffensmeier et al., 2005). This type of conflict occurs when people perceive that there is a huge gap in what they are getting now and what they used to get; and that may fuel tensions among people and lead to discontent (Box-Steffensmeier et al., 2005).

Some scholars seem to agree that groups of people fight together because they perceive themselves as being members of a common culture, ethnic or religious group. And they may be in conflict with others to preserve their cultural identity (Stewart, 2001; Stewart and Fitzgerald, 2001; Steward, 2002). This review on the causes of conflict may not be complete without mentioning Marxist theory of rebellion. This theory hinges on the proposition that market crises could create revolts among the peasant and their masters (employers of labor) who exploit them (Marx, 1850). This is a kind of class conflict because the poor working class is being exploited by the factory owners (employers of labor). The fact remains that prolonged exploitation may lead to revolution or violence. 


\section{Youth Development Framework}

Building a coherent conceptual framework or an outline of the possible course of action will enable the readers to understand the problem facing youth development programs and conflict resolution in Nigeria. Like in other sectors of the polity, the problems bedeviling youth development programs and training in conflict resolution emanates from lack of attention from political leaders on how to help young people (boys and girls) reach their full potential. As noted, youth development framework focuses on evidence-based process, principle and approach that provide young people with the needed supports and opportunities to develop coping skills to become successful adults (YDN, 2014).

The youth are important segment of any society. Therefore, neglecting their needs will expose them to bad influence and push them into anti-social activities. This will threaten the peace, stability and security of the society, and thus, prevent them from thriving socially, politically and economically. Also, understanding the needs of the youth will enable youth development practitioners, parents, and schools (in fact, the entire community) to provide them with life changing experiences and supports to become productive adults (YDN, 2014). The role of the youth as peace-builders in Nigeria (and other countries around the globe) cannot be overemphasized. For the youth to function properly, successful adults with good moral compass should guide them so as to imbibe in them positive values, attitudes and behaviors. This will enable them to learn to make good decisions in time of crisis, resolve conflicts and become good leaders in their communities and promote harmonious relationships among their peers and adults (YDN, 2014).

As noted, 'Youth' is a period of life coming between childhood and maturity; [or] adolescence' or "an early stage of growth or existence" (WNWCD, 2001). And 'development' (as it relates to youth and growth) is "a step or stage in growth..." (WNWCD, 2001). Thus, to develop is to become larger, fuller and better. Put differently, 'development' is "a process of human growth through which young people move from being taken care of to taking care of others and themselves". It is also "an approach in which young people are supported as they build their capabilities and strengths to meet their personal social needs" (YDN, 2014).

This framework has identified five main 'supports and opportunities' that will produce positive results in the lives of the youth (YDN, 2014): a) to provide the youth access to emotionally, physically and culturally safe environment; b) to provide them with caring and consistent healthy adult relationships; c) to provide them experiences and opportunities for meaningful participation in civic activities; d) to provide the youth opportunities to contribute to and gain knowledge of the community in which they live; and e) to acquire applicable skills to engage in challenging and productive activities.

The youth development practices (YDGEYPASP, 2001) that are based on the research by Michelle A. Gambone and James P. Connell also involve "supports and opportunities" the youth need to transit into productive adults (Gambone and James, 1999). The "supports and opportunities" include: Safety: This entails emotional and physical safety. With this, the youth will feel secure that adults will protect them from harm; they will know that they are protected by a set of fair and consistently applied rules or agreement; and feel secure that they will be valued and accepted by the community and their peers. For them, this means building a safe and supportive environment (Gambone and James, 1999; YDGEYPASP, 2001).

Relationship building: This means providing the youth guidance, emotional support, practical support, and knowledge. With that, they will experience those supports and guidance from adults and their peers, and thus, develop functional knowledge of adults and their peers (Gambone and James, 1999; YDGEYPASP, 2001).

Youth participation: This means allowing the youth to make meaningful inputs in decision making process by giving them leadership opportunities, and thus a sense of belonging. In other words, giving them 'guidance and support' the youth will have the opportunity to participate in decision-making and to develop and practice leadership (Gambone and James, 1999; YDGEYPASP, 2001). Community involvement: This means ability to impact the community and build or acquire knowledge of the community in which they live. With this, the youth will have the opportunity to give back to the community or positively contribute to their community development or provide them a sense of connection with the larger community (Gambone and James, 1999; YDGEYPASP, 2001).

Skills building: The youth will be motivated with activities that are challenging and interesting to them and useful to their community; and they will have the opportunity to stretch their knowledge, skills and abilities and perceive their growth, development and progress (Gambone and James, 1999; YDGEYPASP, 2001).

Other critical elements essential for healthy development of the youth (Konopka, 1973; Pittman, 1991) include allowing them to discuss conflicting values (to make mistakes they will learn from and develop coping skills); and they will form their own opinion and feel the pride and accountability that comes with mastery of issues facing them and their community. This will enable them to expand their capacity to enjoy life and to know that success is possible (as cited in "Keys to Quality Youth Development (n.d) developed by Patricia Almquist, et al). According to the youth development approach perspectives of this framework, providing the youth with all these 'basic elements' are among the effective strategies to manage, control and, thus, prevent them from falling into the wrong hands or getting involved in self-destructive activities. The cooperative efforts and influences of the family, school and effective community-based programs are required for all these practices to be possible (YDGEYPASP, 2001).

\subsection{Intervention and Assessment of Youth Development Programs}

The upsurge in youth-related violence and crisis around the globe (including Nigeria) has amplified call for the review and assessment of youth development programs for their efficacy (Hamilton and Hamilton, 2012). For instance, Nigeria has The Federal Ministry of Youth Development devoted to youth development, yet the ministry does not seem to have reliable information about the youth in Nigeria including their unemployment/ underemployment figures and those who need assistance of any kind (The Federal Ministry of Youth Development, 2013). How can the policymakers plan, design and implement effective youth development programs without knowing the number and the needs of the participants? Like in every statistics Nigeria uses in planning, the number of the youth in the population is just a guess work. 
It takes more than political rhetoric to develop the youth in Nigeria and to maximize their success; it takes effective intervention strategies to achieve and sustain positive youth development outcome. Youth intervention strategies should be fashioned in a manner that will meet their needs and specific social, economic and cultural conditions of the society. A development conscious and serious society must develop programs that provide the youth the experiences and skills they need to become creative, innovative and productive, and thus, successful in life. For such programs to be successful, they should be properly planned, implemented, evaluated, and assessed to ensure that they meet the needs of the youth. This is because unmet needs could lead to frustration and social violence.

Thus, any well-planned youth development programs must have the essential tools to empower them with the knowledge and skills they need to become economically self-sufficient. In other words, "they should be able to support themselves and their families". To prevent the youth from getting involved in anti-social activities, the society should provide them with high quality education (including technical and vocational education and skills training with practical application on the job and health education in school and out-of-school) that will enable them to secure decent jobs and change jobs, when and if they need to change jobs (YDN, 2014).

Youth empowerment strategies that are rooted on educational programs and quality skills training must be sustainable if they are expected to make a difference or significant impact on youth development. In addition, the society should provide the youth with the skills and knowledge to participate effectively in conflict management and conflict resolution (Ofem and Ajayi, 2008). The youth program providers and caretakers (parents, extended family and teachers) should be involved in the planning and implementation of youth development programs. And the youth who are the beneficiary of the programs should not be left out in the process of planning, designing, implementation and evaluation of the programs to determine their efficacy (Leffert et al., 1996).

In terms of education and training concerning conflict resolution, participatory approach places equal priority on the relationship with other parties in the conflict to achieve mutual satisfying results (Kepner and Likubo, 1996). The strategies of 'problem solving' and conflict management style are said to include building trust and team, searching for alternative resolutions and 'win-win' solution, instead of "I win, you lose" solution (Kepner and Likubo, 1996). The youth need counseling and other services that will respond to their psychological needs, because unfulfilled psychological needs may lead to frustration, anti-social activities, social unrest and violence. Thus, Nigeria must ensure that the youth have access to potable water, food, warmth, shelter, health care and clean environment, safety and security (to protect everyone from harm). They should also have a sense of belonging and love from family and friends to boost their self-esteem (Yamshon, 2001). These issues have provoked the demand for effective intervention strategies in the planning and implementation of youth development programs (Hamilton and Hamilton, 2012). However, for any youth development programs to make a difference, the society should invest copiously in the programs and increase collaboration among other agencies serving the youth (YDN, 2014).

To bring all this together, the program planners should have clear cut goals and proper indicators to measure their efficacy while building, implementing, and monitoring and evaluating youth development programs. The programs should promote ethnic and religious tolerance, instead of steering division (YDN, 2014). In a multi-ethnic (or tribal) and multi-religious Nigeria, religious tolerance should be one of the key topics of discussion in youth development programs. Societal conflict is said to be rampant in polarized societies.

Conflict management, control and prevention as well as peace-building should be a significant part of any youth development program if Nigeria expects the youth to participate effectively in conflict resolution. Religious leaders and faith-based organizations that are dispensers of religious ideas can play important roles in youth development programs. This approach will help to achieve greater social cohesion and provide critical foundation for enhancing youth development, national integration and economic growth and development (Haynes, 2009). It is worthy of note, in conclusion, that any society that does not satisfy the needs of the youth may degenerate into disorder because violent activities will become their main form of expression.

\subsection{Youth and National Development}

The youth play a prominent role in every society, including national development, as they are seen as the leaders of tomorrow (Gribble, 2010). Their numerical strength is growing in every society, as "Almost half of the world's population is under age 25" (Gribble, 2010). According to literature, the youth between ages 15 and 24 are in greatest needs of social services, including the need for sexual and reproductive health services; and those who are younger will quickly come of age and share the same needs. Literature also show that the size of the population of the world in age bracket of 15 to 24 is hovering around 1.2 billion and it is expected to continue growing for at least 20 more years" (Gribble, 2010).

The youth have creative and modern ideas they acquire from the emerging technologies, and thus, have the potential to propel any society to greatness if their needs are provided. Nigeria's National Youth Development Policy has declared that the youth are the foundation of a society (FRN, 2001). But this pronouncement appears to be the regular rhetoric the policymakers toss around because The Federal Ministry of Youth Development in Nigeria (Abuja), as noted earlier, does not seem to have reliable information on the demography of the youth such as their unemployment/ underemployment figures (Onyeizugbo, 2007). That is the crux of the matter with poor or ineffective youth development programs in Nigeria.

However, the level of investment a nation makes on the well-being of the youth determines the pace of economic growth and development, and security of the nation. Through their creativity, ingenuity, emerging talents and social capital a nation makes a giant stride in economic development and sociopolitical accomplishments. This is particularly the case with societies that have invested copiously on youth development programs and general human capital development (education and health care). This is because "in their dreams and hopes, a nation founds her motivation; on their energies, she builds her vitality and purpose; and because of their dreams and aspirations, the future of a nation is assured" (FRN, 2001).

Drawing from the work of scholars, researchers and practitioners as well as from our own practical experiences as educators, youth coaches and writers, it is not an overstatement to say that the youth are the most active segment 
of any society, and thus, major contributor to peace and stability as well as violence in nations. Despite the myriad problems facing them, the youth in Nigeria have made some impressive inputs on national development through the National Youth Service Corps (NYSC) program, among other activities (FRN, 2001). The society should, therefore, establish other similar programs and properly fund and implement them. More importantly, the participants should be properly motivated (financially) and provided with safe living and working environment.

Since violence is especially a serious problem among the youth (this cannot detract from their role as nationbuilders) we (the authors) can venture to say without fear of contradiction that the degree of lawlessness and instability in a society is also greater among the youth (Dudley, 1973; Aina, 2003). Although developed nations are known to be very good at keeping track of the number of deaths and injuries resulting from youth violence (ILO, 2010) this is not the case with Nigeria. This calls for a serious study/research in this area. Good character education (social and emotional learning) or behaviors and how to build good relationships with adults should be included in schools and youth development programs; with that the society can become a true change maker in the young peoples' lives.

Peace and stability is a harbinger of development in a democratic society (Huntington, 1996). The absence of those in a society means that significant development is unlikely to occur. Nigeria's National Youth Policy has asserted that the youth's "responsible conduct and roles in society is positively correlated with the development of their country" (FRN, 2001). The society should, therefore, provide them high quality education and health care, technical and vocational education and skills training, build a healthy economy as well as good leadership and governance (Dike, 2009; Dike, 2010). This will enable them to go beyond what they perceive as their limits. Although the political leaders, through some development agencies, have adopted a multitude of policies to promote youth development programs in the country, their efficacy remain inadequate. For example, youth development agencies such as Nigeria's National Youth Corps (NYSC) remains grossly underfunded and mismanaged. This has negatively affected the nation's youth development agenda and the social, political and economic development of Nigeria.

Lack of effective youth development programs and conflict resolution skills are therefore among the myriad challenges facing the youth in Nigeria today. These problems are deep-rooted in the seemingly 'anti-growth' "mindset" of the political leaders and the nation's extractive political and economic institutions (Acemoglu and Robinson, 2012). Consequently, there is a serious disconnect between "ego-system thinking and "eco-system reality" (Scharmer and Kaufer, 2013). The state of our mind-sets or mental models affect what we do-our performance, decision-making process, and how we manage ourselves (Senge, 2006). For Nigeria to move forward socially, politically and economically, the political leaders and their followers (in collective, collaborative and shared leadership) must engage in a deeper shift in their "mind-sets" and gravitate toward "eco-system awareness" from their engrained "egosystem thinking" (Scharmer and Kaufer, 2013). Albert Einstein's famous dictum has said it all: "We cannot solve our present problems with the same level of mind-set or consciousness that created them." Thus, what Nigeria will become is the society the leaders and the followers have decided to create.

\subsection{Conflict Management and Resolution Strategies}

Research shows that no single strategy will achieve peace or resolve conflict in any society (Fisher, 2000). Although those who thrive on conflicts will always try to stir the amber of hatred during disputes, but if the society properly educates the youth and the citizens in general, she will create awareness of peace, reduce intolerance and ignorance, and thus, increase social interaction among the many groups in the society. With that, the society or community can manage, control and resolve conflict through collective efforts and with a combination of strategies or actions that will make a real difference (Fisher, 2000).

Some scholars, including Dudley Weeks (Weeks, 1992) have noted three approaches for dealing with conflicts in any social situation: a) Conflict prevention-a process by which individuals and groups select from a wide range of actions, interventions, programs, activities, mechanisms and procedures that can be used to prevent destructive and potentially violent conflict; b) Conflict transformation-a process by which a conflict is changed in a creative way to become a constructive and functional process; and c) Conflict resolution-a process of finding a lasting solution to a conflict by addressing the interest of each party to the extent that both sides are satisfied with the outcome (Weeks, 1992). It has also been observed in Conflict Management in Nigeria (Imobighe, 1997) that conflict management model, which sees conflict management as a process, calls for embracing the three levels of activities mentioned above, namely, "conflict prevention, conflict control and abatement and conflict resolution" (Imobighe, 1997; Academic Association Peace Works (AAP), 2004).

Meanwhile, those who are involved in conflict resolution should at the onset of the process, create an atmosphere or supportive environment where the parties in conflict are really partners in solving the problem (Weeks, 1992). It is most likely that a mutual agreement will be reached when participants in a dispute have given careful consideration to creating such an alluring atmosphere. Some of the major conflict resolution strategies discussed in this article include the following:

Arbitration: This is an action by a third party with authority to decide and enforce settlement. The decision of the arbitrator is binding on the conflicting parties (Fisher, 2000).

Advocacy: This is giving a public support to an idea, a course of action or belief (Hornby, 2006). It means to defend how one feels about an issue by presenting a different point of view. Advocacy may assume different forms such as self-advocacy, which means a person standing by his/her opinion; peer advocacy that takes place when the individual providing the differing view point is going through or has gone through similar experience; and statutory advocacy, which is when a person has legal responsibility (such as a legal practitioner) to represent another person (Hornby, 2006).

Mediation: This is an intervention of a third party in resolving a conflict between two parties (Miller, 2003). It is also "a process guided by a third party that can enable the conflicting parties to find their own agreed settlement" (Fisher, 2000). Mediation is a major collaborative technique (Sacramento, 2013). The mediator is a neutral person 
who has no personal interest in the out-come of the case. He/she is not there as a decision-maker or a judge, but to facilitate the discussion between the disputants. However, the mediator uses his/her expertise in negotiation to get the parties to make informed decisions. There are three phases in mediation: i) introductory phase; ii) problemsolving; and iii) closure (Fisher, 2000).

Negotiation: This is "a process [or a strategy employed in conflict resolution] enabling parties to discuss possible options and reach a settlement through face-to-face interaction" (Fisher, 2000). It has also been described as a structured process of dialogue between conflicting parties (Best, 2006a). The process goes back-and-forth between the parties trying to resolve their conflict with the goal of finding a lasting solution. In successful negotiations, the needs of both parties are put into consideration. A negotiated settlement can become a contract and be enforceable if the parties are satisfied with the outcome or reached a mutually acceptable agreement (Best, 2006b). Other conflict intervention strategies include: i) confidence-building; and ii) facilitating dialogue (Fisher, 2000). For instance, confidence-building involves rebuilding and enhancing mutual respect, trust, and confidence between the conflicting parties, while facilitating dialogue is a process of enabling conflicting parties to have direct communication (Fisher, 2000).

\subsection{Nigeria and Conflict Management Strategies}

Conflict resolution strategies in Nigeria do not appear to have gone beyond the traditional or customary methods of resolving crisis. At best, the society uses some rudimentary modern conflict management or conflict resolution strategies. Generally, in Nigeria when aggrieved parties (individuals and communities) are trying to resolve conflicts/disputes and feel that negotiation would not resolve their problem there is the tendency for them to become agitated and aggrieved. They could at this point resort to violence and strategies that would not move the process forward. When individuals or groups feel that their rights are being violated by powerful political forces they will either resort to violence or engage 'in an all-or-nothing contest' to reclaim their entitlements when their customary strategies fail to yield positive result (FRN, 2001).

The prevailing approach to conflict resolution in Nigeria is rooted in the culture. For instance, conflict management strategies in the Niger Delta region of Nigeria where the communities and oil corporations operating in the area have engaged in an unending dispute/conflict, seem to reflect the conflict management strategies prevalent in the society (FRN, 2001). The conflict management strategies espoused by the participants in conflicts (the communities, the oil corporations and the government) demonstrates how seriously they have identified the issues in dispute. They perceive the conflicts in the region as abuse, rights violation, and injustice against the natives.

The communities in the region (and individuals elsewhere in Nigeria) that feel that they have been marginalized or that their properties have been taken away from them, will be fighting by any means to reclaim their rights. The collapse of 'civic institutions' (because of corruption, poor leadership and governance) have contributed to the delay in the settlement of conflict or resort to traditional strategies. Under intense pressure, the communities through their representatives would take some rash decisions and adopt reactionary strategies and policies that are combative in nature (Onosode, 2003). For instance, the aggrieved communities in the Niger Delta region have a list of demands for the government and oil corporations: they include 'political empowerment' (they claim that their voices have been drowned); increase in monetary allocation from the oil revenue; or outright control of the oil resources to enable them develop the region (Osaghae, 1998).

Some of the strategies adopted to resolve the conflicts in the Niger Delta region (and in other conflict situations such as in labor disputes) include "unorganized and organized verbal threats or agitation; community meetings; sitins and vigils, and written petitions to the oil companies and the government" (Onosode, 2003). Others include media interviews and newspaper publications, delegations to oil companies and government, announcements, mass rallies and demonstrations and temporary occupation of oil installations and premises of oil corporations. Yet, other strategies comprise "abduction of oil corporations' workers, obstructions and disruptions of company operations, legal suits, sabotage, and hostilities between the contending communities and political action" (Onosode, 2003).

These strategies appear to have only succeeded in causing more violence, and thus, intensify the "tension, insecurity and conflicts in the region" (Okoh, 2005).The "win-lose' stance is not conducive to resolving lingering conflict (Coleman, 2003). Alternative strategies such as conflict prevention, conflict control, conflict management and dialogue and other modern conflict resolution strategies with inbuilt participatory approach to conflict management are imperative. This is because they are more likely to produce desired outcome, which is peaceful coexistence and 'win-win' solution (Okoh, 2005; Uwazie et al., 2008).

Although change, as we know it, is constant, it is not easy for people to change from the ingrained belief system. As a result, in communities where they are skeptical about change, the people will more often than not, praise the past and thus prefer to keep the status quo. Thus, during community crisis they could resort to the customary system of conflict resolution where the chiefs and elders in the community would step in to resolve conflicts between aggrieved individuals and groups in the communities. This approach empowers authorities in the community to take active part in resolving conflicts or problems. They think it is 'the way they have always done it' as the conflict resolution based on the customs and belief system was handed down to them by their forefathers. There are also occasions when parents, grandparents and uncles as well as aunties would step in to mediate basic disputes that produce lasting solutions. The first step in resolving a conflict/dispute is to recognize it and respond with effective strategies before it escalates. But for individuals (or the youth) to effectively participate in conflict resolution it is essential that they should have adequate training in conflict mediation and crisis intervention. Nigerians are, thus, advised to "seek dialogue" when they are confronted with conflicts/disputes, instead of "confrontation" to avoid conflicts from escalating into violence (United Nations Development Programme (UNDP), 2003; UNDP, 2005).

\section{Final Conclusions and Recommendations}

Any published work is to a certain degree like an iceberg, because what is visible is only a small portion of the whole. This article has discussed youth development and conflict resolution frameworks for a better understanding of 
issues surrounding youth development and conflict resolution strategies in Nigeria at both individual and group settings. It has also discussed their intervention and evaluation strategies and explored some connections with different disciplines in building plausible theoretical and practical perspectives and procedures to enable readers and policy makers assess and evaluate the efficacy of youth development programs and conflict resolution strategies.

After a thorough review and analysis of pertinent literature and given the findings from their own research on the issues in discourse, the authors of this article have concluded that it is imperative for the political leaders and policy makers to address the myriad pressing needs of the youth in Nigeria. This study has therefore offered the following recommendations, which are by no means exhaustive:

1) To include youth development and conflict resolution strategies as integral part of peacebuilding education in Nigeria's institutions of higher learning to enable the youth learn the importance of peaceful coexistence, cooperation with their peers and cultural tolerance;

2) To establish youth development centers in all the local government areas as part of the youth development initiative to empower the youth and drive development in communities where such resources are lacking or not properly managed.

3) To embrace peace building process through proven youth development programs and conflict resolution strategies;

4) To periodically organize youth development seminars, workshops and conferences in peace building and conflict resolution to enable the people recognize, control and better manage conflict situations;

5) To draft and implement guidelines for youth safety and security in-and-out of school and to make it compulsory for police verification of teachers and youth care givers before hiring them;

6) To ensure that youth development program directors and care givers are properly educated, trained and motivated;

7) To provide proper counselling to the youth to address their needs and concerns about schools and other youth-related activities;

8) To create a supportive environment that will empower the youth to thrive, develop their skills, broaden their scope for action, and to empower them with knowledge and skills to become successful and productive adults;

9) To empower the youth with technical and vocational skills to enhance their entrepreneurial skills to enable them improve their living conditions and, thus, reduce youth-related unrests and conflicts;

10) To create an enabling environment that will allow the youth to start up new businesses, introduce new products and improve their management and leadership skills;

11) To appoint or elected the youth to leadership positions that involve decision making process to enable them participate effectively in conflict resolution;

12) To ensure proper implementation of youth development and conflict resolution guidelines by providing systematic professional development to teachers and other youth development professionals or care givers; and

13) To assess and evaluate the efficacy of youth development activities and program to ensure quality.

The authors, however, hope that this article will contribute to the growing literature on youth development programs and conflict resolution as it has proffered potential solutions to the issues in discourse. It is expected that the knowledge and skills gained (or lessons learned) from this article will enable the reader, and particularly the youth, and their care givers and agencies to plan, design and deliver youth development programs more effectively and efficiently. Given their antecedents, majority of the leaders of Nigeria want power for the sake of power. They are not thinking of developing and implementing effective policies to fix the myriad problems facing Nigeria, particularly in the area of youth development. The growing rate of youth unemployment in Nigeria has been traced to the poor business environment and anti-job creation policies of the government (federal, state and local). The seemingly lack of proper youth development programs (particularly entrepreneurship skills) should be tackled without further delay to sustain national development. It was estimate that of the millions of Nigerians that are unemployed at second quarter of 2016 youth unemployment was about 49.5 per cent (Economic Confidential, 2016). If Nigeria fails to invest in positive youth development initiatives today to educate them (the growing youth population) she will spend billions tomorrow battling youth related conflicts and insecurity in the society.

\section{References}

Academic Association Peace Works (AAP), 2004. A handbook for conflict management and strategic planning for EU MPPs staff and partners organizations. Abuja: Nigeria.

Acemoglu, D. and J.A. Robinson, 2012. Why nations fail: The origins of power, prosperity, and poverty. New York: Crown Publishing GroupA Division of Random House, Inc.

Aina, O., 2003. Cultism and youth violence in Nigerian universities. The center for development and conflict management studies. Nigeria: Obfemi Awolowo University Press.

Akinnaso, N., 2013. Hopeless hopefuls. Punch. Retrieved from www.punchng.com [Accessed December 7, 2015].

Ali, A., 2009. A policy framework for transiting from post-conflict recovery to sustainable development in Sub-Sahara Africa. Journal of African Economy, 18(Supplement 1): i12-i52. View at Google Scholar $\mid$ View at Publisher

Banfield, J., A. Barbolet, R. Goldwyn and N. Killick, 2005. Conflict-sensitive business practice: Guidance for extractive industries. London: SW9 9AP, UK, International Alert.

Barnett, P.W. and S.W. Littlejohn, 2002. Moral conflict: When social worlds collide. Thousand Oaks, CA: Sage Inc, 68.

Best, S.G., 2006a. The methods of conflict resolution and transformation. In Best, S.G. (Editor), Introduction to peace and conflict studies in West Africa. Ibadan: Spectrum Books, Ltd.

Best, S.G., 2006b. Introduction to peace and conflict studies in West Africa. Ibadan: Spectrum, Ltd. pp: 19.

Box-Steffensmeier, J.M., S. De Boef and K. Sweeney, 2005. Multi-level stratified frailty models and onset of civil war. A Paper Presented at the Annual Meeting of the Midwest Political Science Association, Chicago, Il (7-10 April)

Burton, J.W., 1990. Conflict: Human needs theory London: Macmillan and New York: St. Martin's Press.

Burton, J.W., 1990. Conflict resolution and prevention. New York: St. Martin's Press. 
Carson, J., 2015. Nigeria: Time for more international community attention and action-by Johnnie Carson. African Arguments (Editor). Retrieved from http://africanarguments.org/2015/01/19/nigeria-time-for-more-international-community-attention-and-action-byjonhnnie-carson/ [Accessed January 20, 2015].

Cassese, A., 1990. Human rights in a changing. See http://cyd.aed.org/whatis.html; World. updated Edn., Philadelphia: Temple Univ. Press.

Center for Youth Development and Policy, n.d. What is youth development? (Online Publication) Academy for Educational Development. Retrieved from http://www.mwvcaa.org/HYRC/documents/Positive_Youth_Development.pdf [Accessed December 20, 2016]. [Accessed December 2015].

Coleman, P., 2003. Characteristics of protracted, intractable conflicts: Towards the development of a meta-framework. Peace and Conflict: Journal of Peace Psychology, 9(1): 1-37. View at Google Scholar $\mid$ View at Publisher

Collier, P., 2006. Economic causes of civil conflict and their implication for policy. Department of Economics, Oxford University (April, 2006). Retrieved from https://pdfs.semanticscholar.org/c9ba/c0466abef5641c5adf0aef43e4db6a5c60e9.pdf. [Accessed December 20, 2016].

Collier, P., 2007. Post-conflict recovery: How should policies be distinctive? , Mimeo: Center for the Study of African Economies, University of Oxford.

Collier, P. and A. Hoeffler, 2000. Greed and grievance in cold war. CSAE Working Paper, WPS 2002-01 Oxford University. Retrieved from http://www.economics.ox.ac.uk/. [Accessed December 20, 2016].

Community, 2002. Community programs to promote youth development, national research council, institute of medicine. Washington, D.C: National Academy Press.

Cuddy, N. and T. Leney, 2005. Vocational education and training in the United Kingdom: Short description. Greece: European Center for the Development of Vocational Training.

Davis, R. and D.M. Franks, 2014. Costs of company-community conflict in the extractive sector. Corporate Social Responsibility Initiative Report. John F. Kennedy School of Government, Harvard University, Cambridge, MA. pp: 1-56.

Deutsch, M., 2000. Justice and conflict. In handbook of conflict resolution: Theory and practice (M. Deutsch and P. Coleman, editors). San Francisco: Jossey-Bass Publishers, 44.

Dike, V.E., 2009. The relevance of technical and vocational education in Nigeria's development strategy: A new paradigm for effective economic transformation: Research notes/commentaries. African Journal of Science, Technology, Innovation and Development, 1(2\&3): 197-216. View at Google Scholar

Dike, V.E., 2010. Review of youth unemployment, underemployment and poverty in Nigeria: Implications for policy makers. African Journal of Business and Economic Research, 5(1): 91-112. View at Google Scholar

Dike, V.E., A. Ekeh and M. Okpala, 2014. Leadership and governance: Implication on the Nigerian economy. North Charleston, SC: Create Space Independent Publishing Platform.

Dudley, B.J., 1973. Instability and political order: Political and crisis in Nigeria. Ibadan: Nigeria: Ibadan University Press.

Dweck, C.S., 2007. Mindset: The new psychology of success (Paperback). New York: Ballantine Books-An Imprint of the Random House Publishing Group.

Economic Confidential, 2016. Nigeria's economic policies anti-job creation - worldstage summit. Retrieved from http://economicconfidential.com/2016/11/worldstage-economic-summit/ [Accessed November 20, 2016].

Federal Republic of Nigeria, 2001. The national youth policy document of the Federal Republic of Nigeria (updated 2009; also see June 26, 2013), Abuja: Nigeria.

Fisher, S., 2000. Working with conflict: Skills and strategies for action. London: Zed Books Ltd. pp: 95, 65.

Francis, J.D., 2012a. Peace and conflict studies: An African overview of basic concepts. In Best, S.G. (Editor), Introduction to peace and conflict studies in West Africa. Ibadan: Spectrum Books Ltd.

Francis, J.D., 2012b. Peace and conflict studies: An overview of basic concepts. In Shedrack, G.B. (Editor), Introduction to peace and conflict studies in West Africa. Ibadan: Spectrum Books Ltd.

Gambone, M.A. and J.P. Connell, 2004. The community action framework for youth development. Prevention Researcher, 1(2). Retrieved from http://edfundwest.org/wp/wp-content/uploads/2013/10/The-Community-Action-Framework-for-Youth-Development.pdf [Accessed December 20, 2016].

Gambone, M.A. and C.P. James, 1999. Youth development practices involve supports and opportunities the youth need to transit into productive and successful adults. Institute for Research and Reform in Education (IRRE). pp: 18.

Glendon, M.N., 1993. Rights talk: The impoverishment of political discourse. New York: Free Press, 9.

Gribble, J., 2010. Investing in youth for national development. Population Reference Bureau: 1. Retrieved from http://www.prb.org/pdf10/investinginyouth.pdf.

Hamilton, S.F. and M.A. Hamilton, 2012. The youth development handbook: Coming of age in American communities. Thousand Oaks, CA: Sage Publications, Inc.

Hamilton, S.F., M.A. Hamilton and K. Pittman, 2004. Principles for youth development. In S.F. Hamilton \& M.A. Hamilton (Editors), The youth development handbook: Coming of age in American communities. Thousand Oaks: Sage Publications, Inc. pp:3-22.

Haynes, J., 2009. Conflict, conflict resolution and peace-building: The role of religion in Mozambique, Nigeria and Cambodia. Commonwealth \& Comparative Politics, 47(1): 52-75. View at Google Scholar $\mid$ View at Publisher

Hornby, A.S., 2006. See 'concept of advocacy. Oxford advanced learner's dictionary of current english. Oxford: Oxford University Press.

Huntington, S., 1996. Democracy for the Long Haul. Journal of Democracy, 7(2): 3-13. View at Google Scholar $\mid$ View at Publisher

Igbinijesu, N., 2013. Discover Nigeria: Five causes of conflict in Nigeria. Retrieved from Http://www.connectnigeria.com [Accessed December 9, 2015].

ILO, 2010. Global unemployment trends for youth: Special issue on the impact of the global economic crisis on youth. International Labour Office, Geneva: 1-87. Retrieved from http://www.ilo.org/wcmsp5/groups/public/---ed_emp/---emp_elm/--trends/documents/publication/wcms_143349.pdf [Accessed December 20, 2016].

Imobighe, T.A., 1997. Conflict management in Nigeria. In B. Bello-Imam (Editor), Governance in Nigeria: Economy, politics and society in the adjustment Years. Ibadan, Nigeria: Stiring-Horden. pp: 275-280.

International Labour Organization (ILO), 2010. Financial Crisis causes rise in youth unemployment. Geneva: Author. pp: 40.

Kahane, A., 2005. Solving tough problems. San Francisco, CA: Berrett-Koehler. pp: 24.

Kaplan, R.S. and A. Mikes, 2010. Managing risks: A new framework. Harvard Business Review.

Kepner, C.H. and H. Likubo, 1996. Managing beyond the ordinary. New York: AMACOM. pp: 11-28.

Keys to Quality Youth Development, n.d. Developed by Patricia Almquist, Barbara Brekke, Sara R. Croymans, Kari Fruechte, Mary Matlack, Betty McAndrews, Patricia Morreim, Jolie Ogg-Graybill, Barbara Piehl, Joyce Walker, and Tom Zurcher. Extension Center for Youth Development, Child and Youth Development Specialization of the University of Minnesota Extension, St. Paul, MN 55108.

Konopka, G., 1973. Requirements for healthy development of adolescent youth. Adolescence, 8(31): Fall.

Leffert, N., R.N. Saito, D.A. Blyth and C.H. Kroeneke, 1996. Making the case: Measuring the impact of youth development programs. Minneapolis: Search Institute.

Leftkovitz, B., A. Ruiz, S. Mautte and R. Bingham, 2014. Youth development network (see Youth Development Guide). Original Design (2009), by Scott Mautte: 1. Retrieved from www.ydnetwork.org.

Lewin, K., 1952. Field theory in social sciences: Selected theoretical papers by Kurt Lewin. London: Tavistock, 169.

Marx, K., 1850. The class struggles in France (1848-1850). Selected Works, Progress Publishers, 1: 1-78. Retrieved from https://www.marxists.org/archive/marx/works/download/pdf/Class_Struggles_in_France.pdf [Accessed December 19, 2016].

Miller, C.A., 2003. A glossary of terms and concepts in peace and conflict studies. Genera: Univ. for Peace.

Mintzberg, H., 1994. The rise and fall of strategic planning. New York: Free Press. pp: 23.

National Population Commission (NPC), 2013. Abuja, Nigeria. Retrieved from http://www.dailyjobsnigeria.com/tag/national-populationcommission-npc-massive-nationwide-recruitment-in-nigeria-2013/ [Accessed December 20, 2016]. 
National Research Council on Community Programs to Promote Youth Development, 2002. Cited in Jacquelynne S. Eccles; Jennifer Appleton Gootman 2002 Community programs to promote youth development. Washington, DC: National Academy Press.

Nnoli, O., 1998. Ethnic conflict in Africa: A comparative analysis. In Nnoli, O. (Editor), Ethnic conflict in Africa. Nottingham: CODESRIA: 1-25. pp: $3-5$.

O’Higgins, N., 1997. The challenge of youth unemployment. Employment and training paper (7). Geneva: ILO.

Ofem, N.I. and A.R. Ajayi, 2008. Effects of youth empowerment strategies on conflict resolutions in the Niger-Delta of Nigeria: Evidence from Cross River State. Journal of Agriculture and Rural Development, 6(1\&2): 139-146. View at Google Scholar $\mid$ View at Publisher

Okoh, R.N., 2005. Conflict management in the Niger-Delta Region of Nigeria: A participatory approach. African Journal on Conflict Resolution, 5(1): 91-114. View at Google Scholar $\mid$ View at Publisher

Onosode, G.O., 2003. Environmental issues and challenges of the Niger Delta environmental survey process. Chokor, B.A. (Editor). Lagos: Lily Bank Property and Trust Limited. pp: 111-115, 111-124.

Onyeizugbo, E.U., 2007. Perceived causes and consequences of youth unemployment in Nigeria. Nigerian Clinical Psychology, 1: 44-50.

Osaghae, E.E., 1998. Managing multiple minority problems in a divided society: The Nigerian experience. Journal of Modern African Studies, 36(1): 1-24. View at Google Scholar $\mid$ View at Publisher

Patterson, K., J. Grenny, R. McMillan and A. Switzler, 2002. Crucial conversations: Tools for talking when stakes are high. San Francisco, CA: McGraw-Hill. pp: 3, 14.

Pittman, K., 1991. Promoting youth development: Strengthening the role of youth serving and community organizations. Washington, D.C: Academy for Educational Development.

Pittman, K., M. Irby, J. Tolman, N. Yohalem and T. Ferber, 2002. Preventing problems, promoting development, encouraging engagement: Competing priorities or inseparable goals? , Washington, D.C: Forum for Youth Investment.

Positive Youth Development, 2001. National clearinghouse on families \& youth (NCFY). Maryland: Silver Spring.

Ross, M., 2006. A closer look at oil, diamonds and civil war. Annual Review of Political Science, 9(1): 265-300. View at Google Scholar |View at Publisher

Sacramento, 2013. Sacramento Africa Peace Committee Conflict Resolution Training (CACR) Manual. California State University, Sacramento Center for African Peace \& Conflict Resolution.

Scharmer, C.O. and K. Kaufer, 2013. Leading from the emerging future: From ego-system to eco-system economies. San Francisco: BerrettKoehler Publishers, Inc. pp: 11.

Senge, P.W., 2006. The fifth discipline: The art and practice of a learning organization. New York: Doubleday.

Steward, F., 2002. Root causes of violent conflict in developing countries. British Medical Journal, 324(7333): $342-345$.

Stewart, F., 2001. Horizontal inequalities as a source of conflict. In Hampson, F. \& Malone, D. (Editors). From reaction to prevention. London: Lynne Rienner. pp: 105-136.

Stewart, F. and V. Fitzgerald, 2001. War and underdevelopment: The economic and social consequences of conflict. Oxford: Oxford University Press.

Teipel, K., 2002. Minnesota adolescent health action plan (Forthcoming). Findings from key informant interviews conducted by Stephen Conley for the partnership; community programs to promote youth development. Washington, D.C: National Academy Press.

The Federal Ministry of Youth Development, 2013. Abuja: Nigeria. Retrieved from http://www.youthdevelopment.gov.ng/ [Accessed December 20, 2016].

The World Bank, 2007. World bank country-level engagement on governance and anticorruption: An evaluation of the 2007 strategy and implementation plan. Independent Evaluation Group (IEG)-World Bank Group, 1818 H Street, NW, Washington DC 20433. Available from https://ieg.worldbankgroup.org/evaluations/world-bank-country-level-engagement-governance-and-anticorruption [Accessed December 21, 2016].

Thomas, K.W. and R.H. Kilmann, 2010. Thomas-Kilmann instrument conflict mode instrument: Profile and interpretative report (Prepared by Pat Sample) and Interpreted by Jane Trainer, United State and other Countries: Acme, Inc.; CPP, Inc. Retrieved from www.ccp.com; see online: https://www.cpp.com/pdfs/smp248248.pdf [Accessed December 21, 2016].

TWB, 2005. African development indicators. Washington, D.C: The World Bank.

U.S. Department of Health and Human Services, 1996. Reconnecting youth and community: A youth development approach. Washington, D.C: National Clearinghouse on Families and Youth.

Umstot, D.D., 1987. Understanding organizational behavior. Los Angeles, San Francisco: West Pub Co. pp: 18.

UNDP, 2005. Bureau for crisis prevention and recovery (UNDP-BCPR), youth and violent conflict: Society and development in crisis? A strategic review with a special focus on West Africa. Bureau for Crisis Prevention and Recovery.

United Nations Development Programme (UNDP), 2003. Conflict related development analysis; also see UNDP Conflict-related Development Analysis (currently being revised); the 2003 version is here. Retrieved from http://www.scribd.com/doc/40981583/Conflict-RelatedDevelopment-Analysis-2003-UNDP-Bureau-for-CrisisPrevention-Recovery [Accessed December 21, 2016].

United Nations Population Fund (UNFPA), 2012. Population reference bureau (PRB). This publication and the associated interactive map are products of a joint undertaking by UNFPA and the Population Reference Bureau. Retrieved from www.prb.org/Reports/2012/statusreport-youth.aspx. Also see online@ http://www.prb.org/pdf12/status-report-youth-subsaharan-Africa.pdf [Accessed December 21, 2016].

Uwazie, E., 2008. The role of higher education in Conflict resolution and peace education: Challenges and prospect for Nigerian universities. A Lecture at the 24th Convocation Ceremony of the University of Ilorin, Kwara State, Nigeria.

Uwazie, E. and D. Yamshon, 2013. Sacramento African Peace Committee Conflict Resolution Training (CACR) Manual. California State University, Sacramento, Center for African Peace \& Conflict Resolution.

Uwazie, E., D. Yamshon and P. Malberg, 2008. A conflict resolution training manual. California State University, Sacramento Center for Africa Peace \& Conflict Resolution.

Webster's New World College Dictionary, 2001. (Edited by Michael Agnes and David B. Guralnik). 4th Edn., Foster City: CA, IDG Books Worldwide, Inc., pp: 1662, 306, 1220, 394.

Weeks, D., 1992. The eight essential steps to conflict resolution. New York, NY: Jeremy P. Tarcher Inc.

Yamshon, D., 2001. Abraham Maslow's hierarchy of human needs. PowerPoint assembled by Daniel Yamshon based on the theories of Abraham Maslow. CAPCR. Retrieved from www.ADRServicesInternational.com.

Youth Development Guide: Engaging Young People in After-School Programming, 2001. Community Network for Youth Development; 657 Mission Street, Suite 410, San Francisco, CA 94105.

Youth Development Network, 2014. Connecting the research with what we do. Contributing writers: Bina Leftkovitz, Anddrian Ruiz, Scott Mautte \& Rachel Bingham, 5115 Dudley Blvd., McClellan, CA3222: 2-17. Retrieved from www.ydnetwork.org.

\section{Author(s) Biography}

Victor E. Dike ${ }^{1}, \mathrm{EdD}$, is the Founder and CEO of the Center for Social Justice and Human Development (CSJHDEV), an NGO in Sacramento that provides educational and skills training services to the underserved groups in the area. A professional educator, he has more than 20 years of experience in education, ranging from high school/adult education to the university level. Victor Dike was formerly an adjunct professor, School of Engineering, Technology and Media, National University (Sacramento Campus), California. He holds a doctorate in Educational Leadership and Management (with concentration in Human Resource Development) from Drexel University, Philadelphia, Pennsylvania (2013). A prolific writer, he is the author of several books and has contributed chapters to other books. His books include Leadership and Governance: Implication on the Nigerian Economy. North 
Charleston, SC: CreateSpace Independent Publication (co-authored with Dr. Meshack Okpala and Dr. Agatha Ekeh, January 10, 2014); Leadership without a Moral Purpose, BookSurge Publications (2009); and Democracy and Political Life in Nigeria ( $2^{\text {nd }}$ edition), iUniverse, Inc. (2006). Dike has also written numerous peer-review articles including, "Human capital development, technological capabilities and national development: The Nigerian Experience," African Journal of Science, Technology, Innovation \& Development, 2012, 4(2), 11-28; "Planned intervention and organizational development: the role of leadership in Change Initiatives. African Journal of Science, Technology, Innovation and Development, 2014: 1-6; "Leadership and the Nigerian Economy". SAGE Open, March 2, 2014, (4), 1-10; and '“Why Nations Fail” To Develop: The Case Of Nigeria.' SAGE Open, October 28, 2015, 5(4), $1-12$.

Ngozi I Dike ${ }^{2}, \mathrm{PhD}$, is a Chief Lecturer in the Department of Biology, Federal College of Education, Zaria, Nigeria, where she teaches undergraduate students. She has more than twenty five years of teaching experience. She has published several articles both in national and international journals. Her article has appeared in the International Business Research, International Research in Environmental Science and Technology and World Science Journal among other journals and has contributed chapters to text books. 